\begin{tabular}{|c|l|}
\hline Title & Fishing V essel Endangered by Crested A uklet Landings \\
\hline Author(s) & Dick, Matthew H.; Donaldson, William \\
\hline Citation & $\begin{array}{l}\text { The Condor, 80(2), 235-236 } \\
\text { https://doi.org/LO.2307/1367924 }\end{array}$ \\
\hline Issue Date & 1978_04 \\
\hline Doc URL & http://hdl.handle.net/2115/56400 \\
\hline Type & article \\
\hline File Information & condor_80_0235-.pdf \\
\hline
\end{tabular}

Instructions for use 


\section{FISHING VESSEL ENDANGERED BY CRESTED AUKLET LANDINGS}

\author{
MATTHEW H. DICK \\ AND \\ WILLIAM DONALDSON
}

During the night of 16 January 1977, a spectacular wreck of Crested Auklets (Aethia cristatella) occurred aboard the F/V Lynda in Kupreonof Strait between Raspberry and Kodiak islands, Alaska. We interviewed crew members and collected auklets from aboard the 86-foot long crab-fishing vessel in Kodiak on 18 January 1977.

M. Poirier, crew member, related that "We were passing through Kupreonof Strait on our way to Kodiak from Shelikof Strait. We had our bright fishing lights on, as well as our running lights. When I was on watch, between 20:00 and 21:00, I began seeing flocks of birds sweeping back and forth across the strait, low to the water. About two miles NW of Bare Island $\left(57^{\circ} 59^{\prime} \mathrm{N}, 153^{\circ} 08^{\prime} \mathrm{W}\right)$ the birds began to strike the boat in large numbers. When they got close to the boat, they became confused and flew toward the running lights, three of which they broke. The birds did not hit the powerful fishing lights on the mast because they were not flying that high. Thousands of them sat on the water around the boat, and at times the flocks in the air were so dense that they blocked vision from the pilot-house ports. After a half hour or so, birds had accumulated to the top of the bulwarks in the side passageways to at least three feet deep, and were one foot deep on parts of the back deck. The birds blocked the scuppers; the deck did not drain, and the boat listed. The skipper, worried that the boat might swamp, sent the crew of three onto the deck to get rid of the birds. We threw shovelfuls and armloads of birds off the boat for an hour and a half. When we finally realized that the outside lights attracted the birds, we turned them off, and this decreased the number which landed aboard. By the time we reached Chernof Point, we were out of the concentration, though we could still see scattered flocks. We anchored for the night in Whale Passage, where several hundred more birds flew aboard before morning."

T. Richardson stated that "In Kupreonof Strait the wind was blowing 35 to 40 knots from the NE, but the seas were not too rough. The winds and seas were much worse in Marmot Bay, and had we entered it with plugged scuppers, we would have been in danger. The skipper, M. Lynch, who has fished many years in Alaska, says he has never seen a concentration of birds as dense."

When we visited the F/V Lynda in Kodiak Harbor on 18 January, there were still approximately 200 live Crested Auklets underneath a raised plywood platform on the back deck. Another 15 dead birds were found wedged under pipe or caught in the scuppers. A few auklets came out from under the deck every several minutes, but could not fly from the boat because of the high bulwarks. We caught as many as possible and released them into Near Island Channel. Most landed within $200 \mathrm{~m}$ of the boat. Every bird began to bathe as soon as it reached the water. One or two Bald Eagles (Haliaeetus leucocephalus) perching in trees near the channel quickly noticed the auklets, and swooped down at several of them. The auklets dived; we saw none taken.

Eleven live auklets were measured, then released. Eight dead birds were measured, then dissected to determine sex, fat condition and size of gonads. An analysis of the sex and weight measurements is presented in Table 1.

We handled at least 100 birds, and all of them had crests. According to the description given by Gabrielson and Lincoln (The birds of Alaska, Wildl. Manage. Inst., Wash., D.C., 1959) none of the auklets we saw were in their first winter. Of the eight dissected, three were males and five were females. On the fat classification scale of Swartz (Environment of the Cape Thompson region, A.E.C., 1966) the eight specimens ranked from $2-3$ to $4-5$, with an approximate mean of 3 . All contained mediumsized to large masses of visceral fat, though in several cases the amount of subcutaneous fat did not seem correspondingly large. The birds spent two days on deck without food or water, and may have utilized subcutaneous fat without tapping energy from the visceral fat.

The esophagi and stomachs of the eight birds dissected were empty except for a single piece of small ( $1-5 \mathrm{~mm}$ diameter) gravel in each of two individuals. The intestines contained chyme and waste material in all cases.

From the description given by the crew of the Lynda, we estimate that at least 6,000 auklets were aboard the vessel at once. At an average weight of $249 \mathrm{~g}$ apiece, they weighed 1.5 metric tons. One larger bird, possibly a murre, wrecked with the auklets.

Seabird wrecks are not uncommon on fishing vessels and floating processors in Alaskan waters, at least from Kodiak Island westward. Almost every fisherman with two or more years of experience can relate instances where hundreds of seabirds flew onto his vessel, often during a storm, though the conditions of such occurrences seem to vary. According to J. Allen (pers. comm.), several hundred to a few thousand Crested Auklets and from 12 to $15 \mathrm{King}$ Eiders (Somateria spectabilis) flew onto the F/V Jody Ann during each weekly nighttime passage through the Geese Islands $\left(56^{\circ} 44^{\prime} \mathrm{N}, 153^{\circ} 55^{\prime} \mathrm{W}\right)$, off southern Kodiak Island, in March and early April 1973. Half of the eiders would be killed upon striking the boat, whereas over three-fourths of the auklets could be released alive. Mr. Allen also related an incident that a friend of his experienced aboard the F/V Denali in Akutan Pass $\left(54^{\circ} 02^{\prime} \mathrm{N}, 166^{\circ} 03^{\prime} \mathrm{W}\right)$. The back deck became completely filled with shearwaters (Puffinus spp.), apparently during a storm. There were so many on board that the galley door could not be opened. 
TABLE 1. Measurements of Crested Auklets collected on 18 January 1977, from among those wrecked aboard the F/V Lynda on 16 January 1977.

\begin{tabular}{|c|c|c|c|}
\hline Measurement & $n$ & Mean $\pm S D$ & Range \\
\hline Weight $(\mathrm{g})^{1}$ & 11 & $249 \pm 16$ & $221-273$ \\
\hline \multicolumn{4}{|l|}{ Left testis } \\
\hline Length $(\mathrm{mm})$ & 3 & $5.0 \pm 0.9$ & $4.3-6.0$ \\
\hline Width (mm) & 3 & $3.3 \pm 0.6$ & $2.9-4.0$ \\
\hline \multicolumn{4}{|l|}{ Ovary ${ }^{2}$} \\
\hline Length ( $\mathrm{mm})$ & 5 & $13.6 \pm 1.3$ & $13.3-15.4$ \\
\hline Width ( $\mathrm{mm}$ ) & 5 & $4.9 \pm 0.8$ & $3.9-5.8$ \\
\hline
\end{tabular}

A crew member of the $\mathrm{F} / \mathrm{V}$ Polaris told us that a wreck of tens of ducks, including Mallards (Anas platyrhynchos), occurred aboard that vessel in Whale Passage in winter of $1976,16 \mathrm{~km}$ from where the Crested Auklets wrecked on the Lynda.

Irving M. Warner (pers. comm.) observed a wreck of Whiskered Auklets (Aethia pygmaea) aboard the 230-foot long processor Mercator in the Islands of the Four Mountains $\left(52^{\circ} 55^{\prime} \mathrm{N}, 169^{\circ} 40^{\prime} \mathrm{W}\right)$ in early November 1964. The vessel was anchored in the lee of an island during a storm with $80-100$ knot winds. Between 23:00 and 06:00, many Whiskered Auklets were attracted to the outside processing lights, which were on continuously. Most of the birds that landed aboard were killed upon impact. Warner collected all of the dead auklets he could find. The total weight of the casualties was $136 \mathrm{~kg}$, approximately 1,140 birds based upon an individual mass of $119 \mathrm{~g}$, the average of seven measurements taken in the western Aleutian Islands in summer by Vernon Byrd. Gabrielson (in Gabrielson and Lincoln 1959), also in the Islands of the Four Mountains, was hit by a Whiskered Auklet attracted to the boat lights in July 1946 , but stated that this was the only time an auklet came aboard when the lights were being used to attract petrels.

The positive phototropism among certain marine birds, e.g. storm petrels (Hydrobatidae), is well known. However, the phototropic response of Crested Auklets has not previously been documented. Oil and gas development in the Kodiak and other regions, accompanied by the construction of platforms with lights, flaring gasses, or both, pose possible new threats to seabirds.

We acknowledge the editorial assistance of James C. Bartonek.

U.S. Fish and Wildlife Service, 1101 E. Tudor Rd., Anchorage, AK 9.9503. Address of second author: Alaska Department of Fish and Game, P.O. Box 686, Kodiak, AK 99615. Accepted for publication 6 July 1977.

\section{RAVENS ATTRACTED TO WOLF HOWLING}

\section{FRED H. HARRINGTON}

Carrion is important in the winter diet of Common Ravens (Corvus corax; Sutton 1932, Bent 1946, Mech 1966, Temple 1974). Much of it is left from winter kills of large ungulates by predators such as wolves (Canis lupus; Mech 1966). Ravens probably find many carcasses by random search, but they may employ other methods as well. First, they are attracted to a carcass by the calling of ravens already there. Second, they often follow wolves or wolf tracks (Mech 1970:159), and thus, may be present when the wolves make a kill or shortly thereafter. Third, as reported here, ravens may be attracted by wolves howling, and may investigate the vicinity of the wolves for the presence of carrion.

I made the following observations during a study of wolf vocalizations in the Superior National Forest, Minnesota (Harrington and Mech, unpubl.). Human imitations of wolf howls were used to elicit responses from radio-collared wolves. Though most work was done at night, occasional daylight sessions afforded the opportunity to observe raven reactions to the howling.

On 25 October 1972, I found four wolves at the site of a kill of deer (Odocoileus virginianus). Between 12 and 20 ravens were perched in trees directly over the site. At 17:36 I howled and during the wolves' reply, many ravens called and flew about within $5 \mathrm{~m}$ of their perches. When I howled again 20 min later, the wolves did not reply, but three ravens flew $200 \mathrm{~m}$ toward $\mathrm{me}$ in a zig-zag pattern, veering off sharply when $30 \mathrm{~m}$ away.

The next day, in a place far from the preceding observation, I howled several times from a dense stand of tall (10-20 m) spruce (Picea mariana) and balsam fir (Abies balsamea). Shortly after my howls, two ravens flew towards me, hovering briefly over several openings in the canopy as they came. When they reached an opening next to me, both birds quickly veered off and flew away.

On 14 December 1972, I howled as a raven was flying across a large swamp. The bird had been flying $300 \mathrm{~m}$ away from my location in the bordering forest. During my howling, it abruptly changed direction $\left(\approx 90^{\circ}\right)$ and flew along the forest edge toward me. Its path took it about $50 \mathrm{~m}$ from me. When I howled again, the raven changed direction $\left(\approx 60^{\circ}\right)$ once more and passed within $20 \mathrm{~m}$ of me.

On three other days that winter, single ravens approached within 10 to $15 \mathrm{~m}$ of me immediately after I howled. On one occasion, the bird had to fly through a dense grove of balsam fir and birch (Betula papyrifera).

Finally, on 26 August 1973, two ravens were flying past my site, about $200 \mathrm{~m}$ away. During my howling, one of them changed direction $\left(\approx 110^{\circ}\right)$ and flew directly over me. When it was about $50 \mathrm{~m}$ past me, it resumed its former course.

In all these cases, ravens abruptly changed their flying course, approached me, and appeared to search (zig-zag flight, hovering), suggesting that they were attempting to find me. The advantages of such behavior are obvious. In winter, wolves that replied 